\title{
The Snakes of Osun Grove: a World Heritage Site in Osogbo, Nigeria
}

\author{
Akinsola I. Akinpelu ${ }^{1} \&$ Adebowale Areo $^{2}$ \\ 1 Department of Zoology, Obafemi Awolowo University, Ile-Ife, Nigeria; sholakinpelu@oauife.edu.ng \\ 2 National Commission for Museum and Monuments, Ilorin, Nigeria
}

Received 30-IV-2004. Corrected 25-VIII-2006. Accepted 15-I-2007.

\begin{abstract}
The Osun Grove, Osogbo, Nigeria, is a protected area covered by riparian forest, dry high forest and derived savanna. In January and June 2000 a total of 25 of snake species were recorded with Afronatrix anoscopus and Calabaria reinhardti being prominent. The incidence of Philothamnus semivariegatus, a savanna species, may be the result of the invasive savanna produced by farming activities around the grove. Nine species, led by A. anoscopus, accounted for $69.7 \%$ of the snake community. The dominant species are either aquatic or terrestrial, with the exception of Boiga blandingi and Dendroaspis viridis that can be both arboreal and terrestrial, and $C$. reinhardti that is fossorial. Arboreal species mostly preyed on tree frogs and birds including eggs and nestlings, and the aquatic forms preyed on fish and frogs. Mammals, reptiles and toads constitute the prey items of terrestrial species while fossorial species feed on annelids, molluscs, arachnids, myriapods, hexapods, amphibians, reptiles and mammals. Rev. Biol. Trop. 55 (2): 717-721. Epub 2007 June, 29.
\end{abstract}

Keywords: Osun grove, snakes, species richness, abundance, niche segregation.

Throughout the tropics, the original vegetation is rapidly being replaced by cultivated plants, urban development or by other products of human activity. Hence, in Southwestern Nigeria, most of the primary forests have already disappeared except in areas designated as "National Parks or Game Reserves" and culturally protected sites. One of the culturally protected sites is the Osun Grove, located in Osogbo $\left(7 \mathrm{E} 36^{\prime} \mathrm{N}, 4 \mathrm{E} 35^{\prime} \mathrm{E}\right)$, a town in Southwestern part of Nigeria $\left(4^{\circ} 10^{\prime}\right.$ and $6^{\circ} 00^{\prime}$ $\mathrm{N}, 2^{\circ} 45^{\prime}$ and $\left.8^{\circ} 35^{\prime} \mathrm{E}\right)$. The grove which covers an area of $750000 \mathrm{~m}^{2}$ is almost encircled by the Osun River and is also the site of shrines to the Yoruba deities which normally attract visitors from Brazil, the Caribbean, Europe and United States of America. The grove is subdivided into sub-forests on the basis of the deities therein to which names are given. Three vegetation types are present in the grove viz: The Riparian Forest, dry high forest and derived savanna. Most of the grove is covered by high forest. The canopy structure of the riparian forest and dry high forest is irregular, with crowns at all levels, due to the mixed composition of species, ages and size classes of trees. The largest trees belong to the category of emergents, and usually have large wide-spreading well-separated crowns. These provided most of the commercial timbers eg. Lovoa trichilioides, Milicia excelsa, Sterculia rhinopetala, Terminalia superba, Triplochiton scleroxylom, etc. The middle stratum species have relatively slender boles and small crowns, while the under storey consists of trees with short boles and spreading flattish crowns. Below these are the shrub and herb layers, whose density depends on the amount of disturbance to the forest. Woody climbers and epiphytes are frequent, hanging from boles and branches of the trees. Oil palms are found, although usually scarce.

The derived savanna/grassland are in two locations within the grove. A larger portion 
located towards the Southeast portion of the grove contains common grass species like Andropogon tectorum, Imperata cylindrical, etc. The shrubs and trees include Acacia ataxacantha, Anthoeleista vogelii, Elaeis guineensis, Albizia zygia, Cola milleni (Plate 3). Other details of the vegetation and relationship between climate and vegetation are given by Schiotz (1963).

The herpetofauna of Osun grove, (now a World Heritage Centre, sponsored by Osun Grove Support Group and NC-IUCN Netherlands according to UNESCO (2005)), was surveyed within the framework of other zoological and botanical inventories because the primary forest is still extant in most areas of the grove. The grove is equally known to house the endangered White-throated monkey, Cercopithecus erythrogaster and threatened tree species like Afzelia africana, Entandrophragma candoleii, Guarea cedrata, M. excelsa, Pseudospondias microcarpa, etc. Records of snakes from specific areas of the Nigerian forest zone have come from Romer (1953), Blackwell (1967), Joger (1981) and Butler and Reid (1986).

This paper presents the records of snakes within the grove in terms of species richness and abundance to augment attempts at compiling a list of Nigerian snakes.

\section{MATERIALS AND METHODS}

The survey involved extensive systematic combing of the study site, for four weeks. A total of 28 days was spent in the field between January and June 2000. On these days $84 \mathrm{~h}$ were spent carefully searching the forest on foot ( $78 \mathrm{~h}$ by day- $6 \mathrm{~h}$ by night). When a sighting was made, the time, nature of habitat, number, activity and identity of the sighting were noted. Captured specimens were examined, identified and then released at the capture site. Others were merely observed, through telescopic lens and photographed using Zenith TTS LR with $56 \mathrm{~mm}$ lens for subsequent identification using the keys provided by Leeson (1950), Hughes
(1985) and Schatti (1985). Two officials of the National Commission for Museums and Monuments were co-opted into our searches to complement our efforts.

\section{RESULTS}

Table 1 shows that a total of 25 species of snakes belonging to seven families were recorded for Osun grove during the period of study and out of this, the families Colubridae and Viperidae accounted for $64 \%$ and $12 \%$ of the species respectively. A. anoscopus which accounted for 18 specimens out of a total of 109 specimens represented $16.5 \%$ of the snake community. This species together with the next eight abundant species, ie. Natriciteres variegata (13), Dendroaspis viridis (9), Mehelya poensis (7), Boiga blandingii (7), Calabaria reinhardti (6), Bitis gabonica (6), Mehelya crossii (5) and Grayia smythii (5) constituted $69.7 \%$ of the entire snake community. The remaining species made up almost $30 \%$. Out of the 25 species, 11 species had in their diet amphibians and another 11 species had reptiles mostly lizards.

\section{DISCUSSION}

The herpetofauna of Osun grove is not known although it shares the same vegetational structure with rain forest zone of Southern Nigeria. Most of the original primary forest had disappeared and are being replaced by secondary regrowth forest except within the confines of the grove where, due to cultural protection, it still flourishes. Two species, Afronatrix anoscopus and C. reinhardti considered by Butler and Reid (1990) to be either scarce of non-existent in southwestern Nigeria were recorded. Philothamnus semivariegatus known to be a savanna species is gradually finding its way into the forest zone through cultivated forest areas thus confirming the suggestion of Menzies (1966). Several of the remaining recorded species were known to exist in Nigeria. 
TABLE 1

Species, activity, microhabitat and prey items in Osun grove snake community, Osogbo, Nigeria

Taxon

Activity

Microhabitat

Prey

\section{Reference (abundance)}

Boidae

Calabaria reinhardtii (6)

N

F

Colubridae

Afronatrix anoscopus (18)

D

$\mathrm{Aq}$

Aparallactus lineatus (2)

$\mathrm{N}$

F,T

Boiga blandingii (7)

D

A,T

$6,7,8$

Boiga pulverulenta (2)

D

A,T

Bothrophthalmus lineatus (1)

Crotaphopeltis hotamboeia (3)

$\mathrm{N}$

5

Gastropyxis smaragdina (1)

D

5,6

Grayia smythii (5)

D

4,5

Mehelya crossii (5)

$\mathrm{N}$

Mehelya guirali (1)

6,8

Mehelya poensis (7)

$\mathrm{N}$

6

Natriciteres variegata (13)

D

6

Philothamnus heterodermus (1)

D

4,5

Philothamnus irregularis (2)

Philothamnus semivariegatus (3)

Psammophis elegans (2)

Elapidae

Dendroaspis viridis (9)

D

A,T

7,8

Naja nigicollis (2)

D

$\mathrm{T}$

\section{Leptotyphlopidae}

Leptotyphlops bicolor (4)

Pythonidae

Python sebae (3)

Typhlopidae

Typhlops punctatus (1)

\section{Viperidae}

Bitis gabonica (6)

Causus maculates (1)

D

$\mathrm{T}$

Activity: $\mathrm{D}=$ Diurnal; $\mathrm{N}=$ Nocturnal. Microhabit: $\mathrm{Aq}=$ Aquatic, $\mathrm{A}=$ Arboreal; $\mathrm{F}=$ Fossorial; $\mathrm{T}=$ Terrestrial. Prey: $(1=$ annelids and Molluscs; $2=$ arachnids and myriapods; $3=$ hexapods; $4=$ fishes; $5=$ amphibians (Anurans and Caecilians); $6=$ reptiles (Lizards and snakes); 7= Birds (adults, nestlings and eggs); 8= Mammals (rodents, bats \& large mammals). 
The dominant species were either aquatic or terrestrial with the exception of $B$. blanding $i$ and $D$. viridis that can be both arboreal and terrestrial, and C. reinhardtii that was fossorial. No nocturnal aquatic and arboreal snakes were encountered. This was not unexpected in the aquatic forms in that it was an antipredator strategy of ectothermic reptiles. Arboreal species mostly preyed on tree frogs and birds including eggs and nestlings, and the aquatic forms preyed on fish and frogs. Mostly, mammals constituted the diet of arboreal, terrestrial and fossorial species. All these demonstrated a great trophic diversity of Osun grove snake community.

Species richness data from countries like Central African Republic, Gabon, Ghana and Nigeria (Chabanaud 1921, Leston and Hughes 1968, Trape 1985, Butler and Reid 1990) ranged between 35 and 73 species. It is worthy of note that these species included Guinea, Sahel and Sudan Savanna species as well as mountain vegetation species. The 25 species recorded for the relatively small forest enclosure (Osun grove) presented a rich snake community similar to the records of Butler and Reid (1986) on the snakes from Cross River State, Nigeria. This region is still continues with the rain forest belt of Nigeria but on the eastern part of River Niger. It is, however, very likely that the number of species recorded during the present study could be exceeded if the study period was extended and specimens were allowed to be taken for laboratory examination in order to determine actual food preference, reproductive state and parasitic infections.

\section{ACKNOWLEDGEMENTS}

We are indebted to the Ataoja of Oshogbo, Oba Iyiola Matanmi and National Commission for Museums and Monuments, Nigeria for giving us the permission to work within the grove. The contributions of the staff of the
Commission based in Osogbo cannot be quantified, Mr. Fatau was tirelessly helpful.

\section{RESUMEN}

Se registró un total de 25 especies de serpientes en la arboleda de Osun en Osogbo, Nigeria, incluyendo prominentemente dos especies consideradas escasas en el sudoeste de Nigeria: Afronatrix anoscopus y Calabaria reinhardti; Philothamnus semivariegatus, una especie de la sabana, es común posiblemente debido a las actividades de cultivo fuera de la reserva. Junto con las ocho especies abundantes siguientes, $A$. anoscopus, representó el $69.7 \%$ de la comunidad de serpientes. Las especies dominantes son acuáticas o terrestres, con excepción de Boiga blandingi y Dendroaspis viridis que son arborícolas y terrestres, y C. reinhardti que es fosorial. Las especies fosoriales tienen mayor diversidad trófica.

Palabras clave: Nigeria, serpientes, riqueza de especies, abundancia, segregación de nichos.

\section{REFERENCES}

Blackwell, K. 1967. A preliminary survey of the reptiles of the Ibadan area. Br. J. Herp. 3: 307-310.

Butler, J.A. \& J.C. Reid. 1986. Habitat preferences of snakes in the southern Cross River State, Nigeria, p. 483-488. In Z. Rocek (ed.). Studies in Herpetology. Charles University, Prague, Czech Republic.

Butler, J.A. \& J.C. Reid. 1990. Records of Snakes from Nigeria. The Nigerian Field 55:19-40.

Chabanaud, P. 1921. Contribution à l'ètude de la faune herpétologique de l'Afrique Occidentale-Deuxième note. Bull.Com. Ètud. Hist. Sci. Afr. Occ. Fr., Paris 4: 445-472.

Hughes, B. 1985. Progress on a taxonomic revision of the African green tree snakes (Philothamnus spp.), p. 511530. In K.L. Schuchmann (ed.). Proc. Intern. Sym. African Vertbr. Systematics, phylogeny and evolutionary ecology. Zoologisches Forschungsinstitut und Museum Alexander Koenig, Bonn, Germany.

Joger, U. 1981. Zur Herpetofaunistik Westafrikas. Bonn. Zool. Beitr. 32: 297-340.

Leeson, F. 1950. Identification of snakes of the Gold Coast. The Crown Agents for the Colonies, Millbank, London. 142 p. 
Leston, D. \& B. Hughes. 1968. The snakes of Tafo, a forest cocoa-farm locality in Ghana. Bull. Inst. Fr. Afr. Noire 30: 737-770.

Menzies, J.I. 1966. The snakes of Sierra Leone. Copeia 1966: 169-179.

Romer, J.D. 1953. Reptiles and amphibians collected in the Port Harcourt area of Nigeria. Copeia 1953: 121-123.
Schatti, B. 1985. Systematics of East African species of Meizodon Fischer, 1856 (Reptilia Serpentes Colubridae). Monit. Zool. Ital. 20: 149-175.

SchiØtz, A. 1963. The amphibians of Nigeria. Vidensk. Medd. Dansk. Naturh. Foren, Kbh. 125: 1-92.

Trape, J.F. 1985. Les serpents de la region de Dimonika (Mayombe, République Populaire du Congo). Rev. Zool. Afr., Bruxelles 99: 135-140. 
